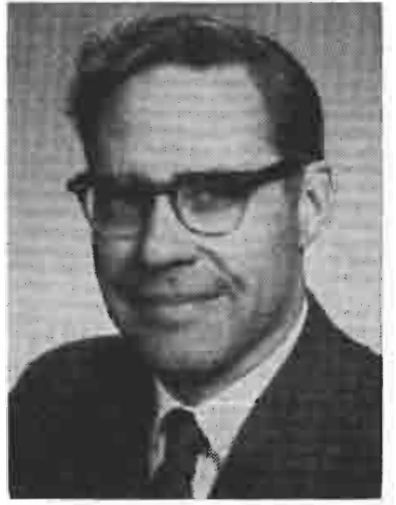

The real Giles sans topper

The CIF Scene

\title{
On slaying dragons
}

At a meeting Art Racey and I had recently with the Northern Ontario Section, the comment was made, "The problem is we don't have any dragons to slay these days, and you can't get people excited unless they are slaying dragons." We were discussing some of the current issues of concern in the CIF and the problem of maintaining member interest and involvement, particulary in Sections where the membership is widely scattered geographically. Members of the Executive Committee have visited 17 Sections in the past year and we have learned that this is a problem common to a number of CIF Sections. Various suggestions for improvement were made but no real solution emerged.

Later I thought about the comment and did a mental flashback to the dragons of the past. In presenting Ken Fensom with the Forest History Society Award in Fredericton, Herb Winer said, "History never truly repeats itself, but we are imposing unnecessary burdens on our strengths and insights if we deprive ourselves of the opportunity to learn some lessons from the record of the past, carefully preserved and wisely interpreted." My recollections of past challenges met by the CIF are partly recorded in the Fenson History, partly drawn from discussion with members, and partly based on my own remembrance of events over the last twenty-five years. What insights do these provide as a guide to future action in the CIF?

In the early 1940s the CIF, as a national body, had foreseen the great potential in returning veterans and had urged the universities to ensure staff and facilities to accommodate a possible large influx of forestry students. Governments and industry were asked to undertake modern forestry programs to close the 20-year gap since the initial surge of forestry activity in the $1920 \mathrm{~s}$. In the immediate post-war period, from 1946 to the mid-1950s, a large number of forestry graduates emerged from the four forestry faculties in Canada. Their challenge was to apply their newly-won qualifications to bringing Canada's forests under improved management through inventory, planning. insect and disease research, logging and teaching. Professional foresters and managers had waited a long time to have the staff capability to do the jobs they had prepared their companies and governments to carry out after a war which followed the Great Depression. Both of these events had greatly reduced the annual number of graduates.

In British Columbia the recently-established Professional Foresters' Association gave an aura of professionalism to the work of the new graduates. But foresters still had to prove themselves in a logging-oriented community. Quebec and New Brunswick had professional associations of long standing. Ontario, on the other hand, had no professional association and many of the new graduates were very active in promoting such an organization. They were also impatient with what they thought was a lack of activity and interest in the CIF and alumni associations. In due course an association was formed in Ontario as well. Older colleagues wisely gave the new graduates the opportunity to incorporate their fresh ideas of action and progress into well-established existing programs.

Several members of two, three or four years' experience became officers of the Sections and in due course members of the Board of Directors of the national body. Their colleagues welcomed this display of vigour and interest and gave them the necessary support to realize their objectives. A real sense of purpose and vitality developed in most Sections where this had happened.

Public information and education were part of some Section programs. One Section bought a tree farm as a demonstration forest. And social activities, such as dances and dinners, were an integral part of CIF life.

August 1973 The Forestry Chronicle 
There seemed to be many dragons in the woods and CIF members were busy slaying them and at the same time enjoying each other's company.

What happened? Are there no dragons today? Where are the young activists? Is the "old guard" holding the reins and discouraging younger participants? Is non-involvement the "in" thing? Is professional esprit de corps outdated?

A number of answers emerge, and the situation differs across the country.

There are Sections where the younger members - urged by their older colleagues, I hope - seem to be in charge. They respond to local challenges by organizing good meetings, submitting briefs to governments, conducting local citizens on "show me" tours, getting involved in Man and Resources, responding to National Executive initiatives, meeting other groups involved in planning land management and economic development. Generally, they give the appearance of being active Sections.

Some Sections, however, are quite inactive. Even the most active Sections acknowledge shortcomings. No dragons, you say? I don't believe it!

Take a look behind that large bush called "Communications." There are several fire-eaters there.

Dragon 1. Is the relationship between company and government foresters in your area what it should be? The CIF can bring them together and develop ideas and a rapport from which society and forestry will benefit.

Dragon 2. Do the school teachers in your area really understand why you cut down trees? The CIF can be a neutral ground where industry, government and educators themselves explain what forestry is all about. The result will be better informed teachers and students with more understanding and intelligent appreciation of what they see around them. Both company and government programs are sometimes suspect. The CIF brings both interests together and a Section can present the program which has a credibility neither can achieve alone.

Dragon 3. Do you think that the local media in your area present reasonable programs about resources, recreation and land management? Most television and radio stations welcome expert help and most newspapers print well-presented items as news or features.

Dragon 4. Do your Chamber of Commerce members really know where the raw material for your mills comes from? Or do the businessmen in your community deplore the harvest process while they use the roads it provides as a means of access to hunting and fishing? A "show me" tour helps explain the facts of life in a forest-based community.

Dragon 5. Can you explain clear-cutting clearly? The day is not far off when you will have urbanoriented critics scrutinizing your operations closely. Perhaps you already have! Professor Harry Smith wrote an enlightening paper for the Seventh World Forestry Congress entitled "The Communication of
Research to the Operational Forester." Our former Forestry Chronicle editor made several excellent points. He outlined the problem from both the researcher's and the operational forester's view. He recognized the need for more rapid and sophisticated electronic communication of research findings and operational needs and also the value of face-to-face transmission of information and ideas. My own experience suggests that the next best thing to sitting on a log in the bush with one or two research foresters is a CIF Section meeting where researchers and operators argue vigorously about what should be done and what can be done. When was the last time your Section arranged such a confrontation in the woods?

Dragon 6. When did your Section last meet with the local MPs and MLAs to tell them your views about today's needs in resource management. My February column gave my opinions on that type of communication. You are constituents after all!

Dragon 7. Have you brought together lately a group comprising foresters, biologists, recreationists, economists, geographers, naturalists and executives to sort out your views about land management and resource development in your area? It could be an interesting evening.

Those are a few of the dragons behind the "Communications bush." What about the "Education bush"?

Dragon 8. All six university programs in forestry are undernourished in facilities, staff and research funds. Is your Section tuned in to the situation? Are you supporting the efforts of the Deans who seek government and other support to meet the needs of future employers? Environmental forestry is upon us. The applications from enthusiastic young Canadians far exceed the places available at Canadian schools. The interest and opportunity are there; can we respond? CIF Sections could be of great assistance in this field. You could find out the situation, decide your viewpoint, and tell your universities and governments about it. Your future may depend on it, so why not have your Section look into it and take appropriate action? You could also help in both recruitment of top students and placement of graduates.

CIF dragons. The CIF itself harbours some dragons. Perhaps the most challenging is the decision to be made next October in Prince Albert about membership classes. Reference to my column in the April Chronicle will refresh your memory about that. Has your Section thoroughly considered the question? Will your Director express the Section's view at the Prince Albert Board of Directors' meeting? Will your Section be represented at the Board of Directors' meeting?

What is the average age of your members attending Section meetings? Are the young members and potential members coming out to meetings? Why not let them take over and encourage them to plan and organize programs relevant to tomorrow's resource management?

The CIF also has budget problems. As an undernourished national organization we are struggling to meet the objectives we have set out in our By- 
laws. Without adequate funds we are unable to do an effective job. The finance committee was asked at last year's annual meeting to examine the financial requirements of the Institute. They will bring to the annual meeting in Prince Albert a recommendation for adequate financing of the Institute's programs in the immediate future. Can we not slay that dragon once and for all?

Speaking of Prince Albert, are you up to date in Canadian forestry? The 1973 meeting will be devoted to identifying today's benchmarks in all aspects of forestry from ERTS Imagery to Environmental Impact of Harvesting. Will you be there?

Have you slain any dragons lately? I hope this column has identified a few challenges for the CIF. Their importance is no less than those earlier dragons our Northern Ontario Section member was thinking about. Every Section has a few dragons and needs knights to deal with them deftly. Can they count on you?

\section{J. Walter Giles}

\section{J. D. B. Harrison}

Dr. J. D. B. Harrison, whose work in forestry has had a worldwide influence, died in Ottawa June 24 at the age of 76 .

Dr. Harrison had a long career in forestry with the federal government and was among the planners of the UN Food and Agriculture Organization, an agency he later served in a senior capacity. He returned from FAO to Canada in 1951 to rejoin the federal forestry service and in 1960 was appointed the first federal deputy minister of Forestry.

A native of Edmonton, Dr. Harrison received his early education in New Brunswick and graduated in forestry from the University of New Brunswick following distinguished World War One service in France and Russia. He received his MSc in forestry in 1934 from UNB. He was honored in 1958 by his alma mater with an honorary doctor of laws degree for his great contributions to the profession.

Dr. Harrison retired as deputy minister in 1962 capping a career that began in 1924 when he joined the federal forestry service. Among his many publications was the first forest inventory of Manitoba in 1934 and his account of it, Forests of Manitoba, was the principal source of information on that province's forests for some 20 years. His Economic
Aspects of the Forests and Forest Industries of Canada published in 1936 was of major significance in focusing attention on the growing importance of the forests in the national economy.

In 1940, Dr. Harrison was ap. pointed chief of the Economics Division of the Dominion Forest Service. During World War Two he left this post to serve as Assistant to the Deputy Timber controller in the Department of Munitions and Supply from 1942 to 1945 . He helped in the formation of the United Nations FAO as a member of the technical committee on forestry to the preparatory commission which met in Quebec in 1945.

He later accepted a five-year term with the FAO as chief of the economics section of the forestry and forest products division. During this period his contribution to world forestry was outstanding, particularly in his authorship of the FAO publication Planning a National Forest Inventory. This work has been widely acclaimed for its clear and concise presentation of the principles and practices involved in making forest resource inventories.

He played a prominent part in organizing FAO's North American Forestry Commission (of which he was chairman at the time of his retirement in 1962). In recognition of his services to the Com- mission he was given one of Mexico's highest awards.

In 1951 Dr. Harrison returned to Canada to become Chief of the Forest Research Division of the Forestry Branch, Department of Resources and Development. $\mathrm{He}$ instituted a five-year development plan which brought a fresh and clear orientation to the Branch's forest research program. On his appointment as Director of the Forestry Branch in 1956, Dr. Harrison used to full advantage the opportunity this afforded to focus attention on the need for greatly increased research, and the needed funds for applying research results in the improvement of forest management practices.

After retirement in 1962, Dr. Harrison continued to contribute his service to forestry in many ways. He served as federal government member of the Eastern Rockies Forest Conservation Board from 1966 to 1971 and wrote a number of important forestry articles.

Dr. Harrison was president of the CSFE (CIF) in 1943 and 1944; in this capacity he was responsibe for the preparation of the Institute's statement on forest policy. He was made an honorary member of the CIF in 1965. He was also a member of the Commonwealth Forestry Association and the Society of American Foresters. 